\title{
АНТИФОСФОЛІПІДНИЙ СИНДРОМ ТА УРАЖЕННЯ ЛЕГЕНЬ
}

\section{Антифосфоліпідний синдром та ураження легень}

\section{Н. Я. Мехно, О. 3. Яремчук}

Тернопільський національний медичний університет імені І. Я. Горбачевського МОЗ України

Резюме. Антифоссроліпідний синдром характеризується венозним та артеріальним тромбозом $i$ тяжкими ускладненнями, що призводять до частих летальних наслідків. Продукція антифосфоліпідних антитіл (антикардіоліпінові антитіла, антитіла до $\beta_{2}$-глікопротеїну I та вовчакові антитіла) сприяє ушкодженню, головним чином, ендотелію судинної стінки, що запускає механізм гіперкоагуляції та тромбоутворення під впливом зовнішніх чинників. Антифоссроліпідні антитіла можуть сприяти розвитку диссрункції органів через механізми імунної відповіді та системи гемостазу, пов'язані між собою. їх вплив на легеневу систему, який недостатньо вивчено, є важливим для вчасної діагностики антиоросфоліпідного синдрому.

Мета дослідження - проаналізувати та систематизувати літературні джерела, щоб оцінити частоту та причини виникнення антифоссроліпідного синдрому, його патогенез та механізми ураження легень на фоні даного захворювання.

Матеріали і методи. Опрацьовано матеріали з інформаційних «Internet»-ресурсів, публікації закордонних та українських фрахових видань, медичної бази даних MEDSCAPE/PubMed за останнє десятиріччя.

Результати. Клінічні дослідження пацієнтів з антифросфроліпідним синдромом із легеневими ускладненнями показали неоднозначність у підходах верифрікації та лікування. Точна причина виникнення даного синдрому остаточно нез'ясована. Головними наслідками його $\epsilon$ активація системи гіперкоагуляції та тромбоутворення, що зумовлює ішемію тканин чи викликає, навіть, поліорганну недостатність. Це провокується утворенням трьох типів антифоссроліпідних автоантитіл. Проте антифосфоліпідні антитіла не завжди виявляють у хворих з антифоссроліпідним синдромом, які мають клінічні прояви. Тоді діагностують серонегативний антифросфоліпідний синдром. Клінічний спектр проявів, пов'язаних із наявністю антисросороліпідних антитіл, поступово розширюється, включаючи опис декількох легеневих проявів. Сюди належать тромбоемболія легеневої артерії, легенева гіпертензія, гострий респіраторний дистрес-синдром, оріброзуючий альвеоліт. Однією з інсрекційних хвороб, при якій утворюються антифроссроліпідні антитіла, $є$ SARS-

\section{Antiphospholipid syndrome and pulmonary involvement}

N. Ya. Mehno, O. Z. Yaremchuk

I. Horbachevsky Ternopil National Medical University

e-mail: mekhno_nyar@tdmu.edu.ua

Summary. Antiphospholipid syndrome is characterized by venous and arterial thrombosis and severe complications that frequently lead to deaths. The production of antiphospholipid antibodies (anticardiolipin antibodies, antibodies to $\beta_{2}$-glycoprotein 1 and lupus antibodies) contributes to damage, mainly to the endothelium of the vascular wall, which triggers the mechanism of hypercoagulation and thrombosis. Antiphospholipid antibodies may contribute to the development of organ dysfunction through the interrelated mechanisms of the immune response and the haemostasis system. Their effect on the pulmonary system is studied insufficiently; it is important for timely diagnosis of antiphospholipid syndrome.

The aim of the study - to analyse and systematize the literature in order to assess the frequency and causes of antiphospholipid syndrome, its pathogenesis and mechanisms of lung damage in cases of this disorder.

Materials and Methods. The information from the Internet sources, world and Ukrainian professional publications, medical database MEDSCAPE/PubMed for the last decade has been studied.

Results. Clinical studies of the patients with antiphospholipid syndrome and pulmonary complications have shown ambiguity in approaches to verification and treatment. The exact cause of this syndrome is not understood completely. Its main consequences are the activation of the hypercoagulation and thrombosis that cause tissue ischemia or even multiple organ failure. This is triggered by formation of three types of antiphospholipid autoantibodies. However, antiphospholipid antibodies are not always revealed in the patients with antiphospholipid syndrome with clinical manifestations. Then seronegative antiphospholipid syndrome is diagnosed. The clinical spectrum of manifestations associated with the presence of antiphospholipid antibodies is gradually expanding including the description of several pulmonary manifestations. These are pulmonary embolism, pulmonary hypertension, acute respiratory distress syndrome, fibrous alveoli. One of the infectious diseases in which antiphospholipid antibodies (APA) are formed is SARS-CoV-2, especially in severe cases. Management of patients with complications after COVID-19 is an urgent issue these days. 
CoV-2, особливо за тяжкого перебігу. Ведення хворих з ускладненнями після перенесеного COVID-19 є акmуальним питанням сьогодення.

Висновки. Недостатнє вивчення механізмів ураження легень при антифоосфоліпідному синдромі $\epsilon$ поштовхом для нових досліджень у даній галузі медицини. Розкриття патогенетичних механізмів утворення автоімунних антитіл і їх роль у прогресуванні цієї патології є обов'язковими для постановки чіткого діагнозу. Більшість легеневих ускладнень має тяжкий перебіг, який часто призводить до втрати пацієнта.

Ключові слова: антифосороліпідний синдром; легені; тромбоемболія легеневої артерії; антифосфоліпідні антитіла.

\section{ВСТУП}

Антифоосороліпідний синдром (АФС) належить до набутої форми аутоімунної тромбофрілії, який характеризується хронічними судинними тромбозами, що призводять до поліорганної ішемії, а при рецидивних вазооклюзивних процесах у дрібних судинах внутрішніх органів - до поліорганної недостатності [1, 2]. АФС спричиняє інсульти, транзиторні ішемічні атаки, тромбози поверхневих вен, тромбоемболію легеневої артерії (ТЕЛА), сітчасте ліведо, невиношування вагітності та/чи втрату плода на ранніх термінах. Одним із легеневих проявів АФС $\epsilon$ тромбоемболія легеневої артерії, яка виникає у 14 \% осіб із даним захворюванням. Іншим проявом є легенева гіпертензія, яку виявляють з частотою від 1,8 до 3,5 \% [3]. До легеневих проявів АФС також належить інфаркт легень, гострий респіраторний дистрес-синдром, дифузна альвеолярна кровотеча, альвеолярний капілярит, післяпологовий ідіопатичний фріброзуючий альвеоліт. У пацієнтів, які мають два чи більше одночасних легеневих проявів, можна діагностувати легеневий АФС [1, 3].

Гіперкоагуляція та генералізовані тромбози є одними із перших серед ускладнень, що спричиняють антифроссроліпідні автоантитіла (АФА), що утворюються і циркулюють у крові хворих. До АФА належать антикардіоліпінові антитіла, антитіла до $\beta_{2}$-глікопротеїну-І (aß, GPI) та вовчакові антитіла [1, 4]. Тільки у $30 \%$ хворих із вовчаковими антитілами та у 30-50 \% із АФА проявляються клінічні прояви. У жінок АФА зустрічається в 2-5 разів частіше, ніж у чоловіків та у $20 \%$ АФС є причиною невиношування вагітності [2]. Проте не всі, у кого виявили АФА, мають прояви захворювання. Генетика теж відіграє важливу роль, проте прямої передачі хвороби немає $[2,4]$. Чому саме запускається механізм вироблення антитіл не відомо. Існує актуальна теорія для пояснення патогенезу АФС - це теорія «подвійного удару». В людей, які генетично схильні до даної патологія, тригером виступає зовнішній фрактор, наприклад вірусне захворювання чи стрес, хірургічні
Conclusions. Insufficient study of the mechanisms of pulmonary involvement in antiphospholipid syndrome is the impetus for new research in this field of medicine. Discovery of the pathogenetic mechanisms of autoimmune antibody production and their role in development of this pathology are essential for a clear diagnosis. Most pulmonary complications are severe, often resulting in patient death.

Key words: antiphospholipid syndrome; lungs; pulmonary embolism; antiphospholipid antibodies.

втручання, онкологічні захворювання [4-7]. Самі АФА не впливають на коагуляційні властивості крові, незалежно від того скільки часу вони циркулюють у кровоносному руслі. Зазвичай утворення тромбів відбувається під час супутніх захворювань, наприклад гіпертонічна хвороба, ожиріння, атеросклероз $[2,4,6,8]$

Метою дослідження було проаналізувати та систематизувати літературні джерела, щоб оцінити частоту та причини виникнення антиоросфоліпідного синдрому, його патогенез та механізми ураження легень на фоні даного захворювання.

\section{МАТЕРІАЛИ I МЕТОДИ}

Опрацьовано матеріали 3 інорормаційних «Internet»-ресурсів, публікації закордонних та українських фрахових видань, медичної бази даних MEDSCAPE/PubMed за останнє десятиріччя.

\section{РЕЗУЛЬТАТИ Й ОБГОВОРЕННЯ}

У патогенезі АФС бере участь продукція АФА до негативно заряджених фросороліпідів клітинної мембрани та плазмового білка $\beta_{2}$-глікопротеїну-І $\left(\beta_{2} \mathrm{GPI}\right)$, які під вливом патологічних станів (хірургічне втручання, пологи, інфекція) провокують гіперкоагуляцію та тромбоутворення у пацієнтів. При цьому АФА зв'язуються 3 фосфоліпідами ендотеліальної мембрани судин та тромбоцитів, провокуючи порушення фрібринолітичних процесів, втрату антитромботичних властивостей судинного ендотелію та активацію тромбоцитарних клітин [6]. Вони можуть стимулювати утворення нітроген оксиду та супероксиданіону, чим збільшують виробництво прооксидантих молекул та пероксинітриту. Порушення окисно-відновного балансу супроводжується зниженням антиоксидантних можливостей та помітною диссрункцією мітохондрій, призводять до прозапальних та протромботичних станів в організмі [9]. АФА також провокують резистентність до протеїну C та збільшують захоплення протромбіну, 
таким чином, знижують антитромбінову активність коагуляції. Такий комбінований каскад механізмів запускає ряд мікро- та макротромбозів у венах та артеріях [10]. АФА можуть індукувати активацію комплементу, продукти розщеплення якого ініціюють тромбоз та подальше ушкодження тканин [9]. Також останніми дослідженнями було доведено, що АФС можна віднести до хвороб генетичної природи [10].

Генетичну схильність підтвердили дослідження групи хибнопозитивних тестів на сифріліс у членів однієї родини. Антитіла до кардіоліпіну зустрічаються частіше у людей із системним червоним вовчаком або первинним АФС з першою лінією спорідненості, що вказує на генетичну схильність до утворення аутоантитіл [11]. Вперше генетичну теорію виникнення АФС перевірили на мишах. Спонтанне вироблення антикардіоліпінових IgG, які зв'язуються 3 кардіоліпіном, підтвердили у мишей-самців лінії NZW x BXSB F1 (W/B F1) [12]. У відповідь продукуються автоантитіла, які атакують негативно заряджені фосороліпіди мембран, включаючи фросфатидилсерин та фоссратидилінозитол та утворюють циркулюючі імунні комплекси, що врешті призводить до гломерулонефриту [13, 14].

В основі патогенезу лежить теорія «двох ударів», де першим ударом $€$ активація процесів гіперкоагуляції під впливом циркулюючих антитіл, а другим - вплив локальних тригерних механізмів - фракторів індукування тромбоутворення [2].

Діагностувати АФА можна завдяки ІФА з кардіоліпіновим антигеном; завдяки вовчаковому антикоагулянту; антитіла, що не діагностуються за допомогою стандартних методів (антитіла до білка C та S, тромбомодуліну, гепарансульфрату та інші). Зазвичай лише у третини носіїв АФА з'являються клінічні прояви. Навіть у здорових людей у нормі можна зустріти низький рівень АФА $[2,6]$.

$\beta_{2}$ GPI складається 3 п'яти доменів (I-V). Домен $\mathrm{V}$ має гачкоподібну форму і взаємодіє з фоосороліпідами мембран, а на протилежному боці домен I, який розпізнається більшістю антитіл при АФС $[13,15]$. У плазмі здорових людей $\beta_{2}$ GPI набуває кільцевої конфігурації вільного тіолу, що дозволяє блокувати зв'язування антитіл з епітопами домену І. Окисний стрес трансформує кільцеву конфігурацію в лінійну, оголюючи антигенні детермінанти домену-І, які з'єднуються з патогенними АФА [15]. Антигенними мішенями також $є$ - фосоратидилсерин, тканинний активатор плазміногену, плазмін, тромбін, протромбін, антитромбін III, активований протеїн C і анексин V. Така варіабельність антигенів імовірно пояснює існування серонегативного АФС [13].

Антифросфоліпідний синдром поділяють на:

1. Первинний - виникає за відсутності супутньої автоімунної патології (7-12 \%);
2. Вторинний - виникає за наявності автоімунних та хронічних захворювань, злоякісних новоутворень та приймання деяких лікарських засобів;

3. Катастрофрічний - виникає швидка поліорганна недостатність, зумовлена мікротромбозом кількох внутрішніх органів [16].

Клінічна картина АФС проявляється:

- тромбозом судин внутрішніх органів:

1. Тромбоемболія легеневої артерії, мікротромбоз, легенева гіпертензія;

2. Ушкодження серцевих клапанів та потовщення стулок, дрібні розростання на клапанах, коронарний тромбоз;

3. Тромбоз ниркової вени чи артерії, внутрішньониркова тромботична мікроангіопатія;

4. Інші органи черевної порожнини - синдром Аддісона, інфаркт селезінки, ішемія стравоходу.

- передчасні пологи, викидень, плацентарна недостатність, затримка розвитку плода, прееклампсія;

- транзиторні ішемічні атаки, інсульти, деменція, як наслідок рецидивні мікроінсульти;

- нейропатія зорового нерва, тромбоз центральної вени чи артерії сітківки;

- сітчасте ліведо, виразки та некротичні зміни шкіри бувають рідко;

- майже у половини хворих артралгії;

- катастрофічний АФС - поліорганна недостатність, особливо часто ураження нирок та легень, унаслідок мікротромбозу під впливом провокуючих фракторів - травми, хірургічне втручання, інфекції, стрес, відміна лікарських засобів для розрідження крові $[4,16]$.

У м. Сідней в 2006 р. на конгресі були представлені клінічні критерії антифоссроліпідного синдрому, які поділили на дві окремі групи: тромбоз глибоких вен та артерій різної локалізації - тромботичний АФС, патологія вагітності - передчасні пологи до 34 тижня вагітності на фроні прееклампсії або плацентарної недостатності; загибель морфологічно нормального плода на 10-му або більше тижні вагітності; серія самовільних викиднів (3 і більше) у терміні до 10 тижнів із виключенням хромосомних аномалій, гормональних чи анатомічних причин у жінки [2, 10, 14]. Відповідно були представлені й лабораторні критерії: наявність ізотипів IgG чи IgM антикардіоліпінових антитіл у плазмі чи сироватці крові в високих чи середніх титрах щонайменше 2 рази протягом 12 тижнів за допомогою стандартизованого (ІФА); антитіла IgG чи IgM до $\beta_{2}$ GPI виявлені двічі чи більше в сироватці протягом 12 тижнів стандартизованим методом ІФА; вовчаковий антикоагулянт виявлений 2 або більше разів у плазмі з проміжком не менше 12 тижнів. Діагноз АФС підтверджується за наявності одного клінічного критерію та одного лабораторного, причому перше лабораторне дослідження виконується не раніше 
ніж через 12 тижнів від появи клінічної симптоматики $[2,6,10]$.

При катастрофрічному АФС смертність складає майже 50 \%. Клінічно проявляється поліорганною недостатністю, що миттєво розвивається, гістопатологічні ознаки оклюзії дрібних судин та високі титри АФА [17]. У більшості випадків пусковим чинником, що зумовлював тяжкість захворювання та коагулопатії, були бактерійні та вірусні інфрекції, хірургічні процедури чи злоякісні новоутворення [9].

В Італії у 2002 р. були затверджені критерії катастрофрічного АФС:

- втягнення в процес 3 чи більше органів, систем чи/та тканин (клінічні прояви звуження просвіту судин візуалізовані за допомогою цифрових методів. Захворювання нирок супроводжується підвищеним рівнем креатиніну в сироватці крові на 50 \% та наявністю тяжкої системної гіпертензії >180/100 мм рт. ст.) та/чи протеїнурії >500 мг/добу;

- одночасний та швидкий розвиток проявів (менше ніж тиждень);

- гістологічне дослідження має підтвердити оклюзію дрібних судин хоча б в одному органі чи тканині (мають бути переконливі докази тромбозу);

- наявність вочакового антикоагулянту та/чи антитіл до кардіоліпіну підтверджених лабораторно (якщо АФС був вперше виявлений, то необхідна наявність АФА, які виявлялись 2 або більше разів 3 інтервалом хоча 66 тижнів). Для встановлення АФС потрібне підтвердження усіх 4 критеріїв $[4,10]$.

Легеневі прояви займають друге місце серед ускладнень АФС та включають в себе ТЕЛА і, як наслідок, можливий інфраркт легені та легеневу гіпертензію. ТЕЛА може бути першим проявом АФС [18]. Було вивчено захворюваність та смертність у 1000 пацієнтів із АФС за 10-річний період, які показали, що 14 \% пацієнтів мали ТЕЛА як первинний симптом і повторні епізоди емболії констатували у $3,5 \%$. Смертність у цих пацієнтів становить 5,4 \% [17]. Тромбоз глибоких вен відмічається у $55 \%$ людей хворих АФС і у 30 \% із них наявні епізоди ТЕЛА. Частота рецидивів протягом перших 5 років лікування антитромботичними препаратами становила 7,5 \%. Першим кроком у діагностиці ТЕЛА $€$ визначення рівня Д-димеру та рентгенографія грудної клітки [1].

Для ТЕЛА виділяють дві основні групи фракторів ризику генетичні (первинні) та набуті (вторинні). Вроджений фрактор ризику до утворення тромбів самостійно, практично, не існує, мають бути провокуючі фрактори, які запускають механізм [20]. Наявність спадкових порушень можна припустити при обтяженому анамнезі, тромбоутворенні нез'ясованого генезу в людей до 40 років, часті рецедивні тромбози глибоких вен нижніх кінцівок чи ТЕЛА [19]. Одним із провідних фракторів ризику тромбоутворення $є$ зменшення роботи м'язів ніг, що знижує тонус судин та призводить до застою крові у венах нижніх кінцівок [21].

Класифікація ТЕЛА за МКХ-Х:

1. Масивна - зниження САТ <90 мм рт. ст. чи зниження на $\geq 40$ мм рт. ст. від первинного показника і триває більше 15 хв та не зв'язане з сепсисом, аритмією, гіповолемією; розвивається при перекритті судинного русла більше 50 \%. Супроводжується явищем кардіогенного шоку та/чи артеріальної гіпотензії.

2. Немасивна - розвивається при закупорці менше 50 \% кровотоку, в пацієнтів не порушується гемодинаміка та немає виражених ознак правошлуночкової недостатності.

3. Субмасивна ТЕЛА - це підгрупа немасивної за умов підтвердження на ЕхоКГ ознак гіпокінезії правого шлуночка та стабільної гемодинаміки. Вона виникає при обструкції більше 30 \% судинного русла, але менше 50 \% [19, 21].

За гостротою розвитку виділяють такі фрорми:

- гостра - з раптовим початком, зниженням AT, задишкою, болем за грудниною, ознаками легеневого серця та з можливим початком шоку;

- підгостра - розвиток дихальної та правошлуночкової недостатності, ознаки інораркту легень;

- хронічна рецидивна - повторні напади задишки, ознаки тромбоінфрарктної пневмонії, прогресування хронічної серцевої недостатності з епізодами загострень та поява ознак хронічного легеневого серця $[19,22]$.

Це все є класичними симптомами у пацієнтів, за якими необхідно запідозрити ТЕЛА. Проте симптоми можуть різнитися від раптового колапсу до повільно прогресуючої задишки та мати нестандартні прояви, такі, як судоми, синкопальні стани, абдомінальний біль, лихоманка, продуктивний кашель, кровохаркання, хрипи, втрата свідомості, делірій, початок фрібриляції передсердь та навіть безсимптомний перебіг [23]. Діагностуючи ТЕЛА лікар використовує різні додаткові методи дослідження, такі, як:

- комп'ютерна томографрія та легенева ангіографрія - це метод діагностики першої лінії, бо він є чутливим і специфічним, проте потребує використання контрасту, який є протипоказанням для людей із патологією нирок. Ангіографрія дає можливість оцінити легеневі артерії від стовбура до сегментарних артерій, а КТ - дослідити зміни у легеневій паренхімі та побачити субсегментарні артерії;

- зростання вмісту Д-димеру; в деяких пацієнтів також спостерігається підвищений рівень натрійуретичного пептиду та/чи серцевих тропонінів, який показує перевантаження правого шлуночка;

- рентгенографрія органів грудної клітки - неінвазивний метод, який дозволяє побачити розширення тіні серця, плевральний випіт, високе стояння купола діафрагми, розширення просвіту легеневої артерії, інфільтрати в легеневій тканині та місця 
ателектазу. Проте вона не є основним методом для постановки діагнозу;

- електрокардіографрія - пришвидшений серцевий ритм (тахікардія), може бути надшлуночкова аритмія, зміни зубця Т і сегмента ST; рідше правограма, повна чи неповна блокада правої ніжки пучка Гіса;

- ехокардіографрія - розширення правого шлуночка і розширення міжшлуночкової перегородки можуть бути виявлені у хворих з проміжним чи високим ризиком ТЕЛА; черезстравохідне ЕхоКГ дозволяє побачити початкові відділи часточкових артерій, тим самим частіше дозволяє виявити емболи;

- УЗД глибоких вен нижніх кінцівок $[19,24,25]$.

Тромбоемболія, як ускладнення АФС, несе ризики для пацієнтів. Вона займає третє місце серед захворювань із летальним наслідком [20].

Легенева гіпертензія (Лг) може бути як окреме захворювання, а може - наслідком якоїсь хвороби, наприклад рецедивної ТЕЛА у людей з АФС [26]. Патогенетично, легеневій гіпертензії сприяє проліферація судинного ендотелію та гладкої мускулатури, тромбоз in situ, ураження дрібних легеневих артерій та фрібриноїдний васкуліт усіх типів середньокаліберних артерій [27]. Згідно з нещодавніми дослідженнями, патогенез ЛГ при АФС розділи на три категорії:

а) перехресна реактивність між антитілами до кардіоліпіну та ендотеліальних клітин;

б) дія антиоросороліпідних антитіл на ендотелій судин;

в) можливість антитіл сприяти розвитку лГ [1].

Ехокардіографія дозволяє оцінити рівень тиску в ЛА, що необхідне для остаточної діагностики легеневої гіпертензії. Тиск у ЛА повинен збільшитись на $\geq 25$ мм рт. ст. у спокої та 30 мм рт. ст. - при навантаженні. Ці виміри можна зафріксувати завдяки катетеризації правих відділів серця [28]. Існує припущення, що АФА у хворих із СЧВ теж можуть сприяти розвитку легеневої гіпертензії, що є рідкісним, але небезпечним для життя. Було вказано, що частота легеневої гіпертензії була вищою в АФА позитивних пацієнтів із СЧВ, ніж в АФА негативних і складала, відповідно, 25 і 2 \% [29]. Поширеність розвитку легеневої гіпертензії у пацієнтів з АФС згідно із даними різних досліджень, коливається в межах від 2 до 24 \%. Такі розбіжності пояснюються наслідком відмінних клінічних особливостей пацієнтів та методів діагностики [1].

Легенева гіпертензія характеризується підвищенням легеневого тиску та судинного опору. В основі даної патології лежить спазм судин, реконструкція судинного русла, зменшення еластичності судинної стінки та обтурація легеневих судин (тромбоз, проліферація клітин гладкої мускулатури), що призводить до перевантаження правого шлуночка, прогресування серцевої недостатності, за відсутності лікування - до летальних випадків [28].
Дисорункція ендотелію внаслідок його ушкодження в поєднанні із зміненим рівнем судинноактивних речовин [30] - секреція хемотаксичних агентів, призводить до розростання гладком'язових клітин в інтиму артеріол легень. Таким чином, ураження ендотелію викликає ремоделювання легеневих судин, збільшення їх обструкції та облітерації [26].

Класифрікація легеневої гіпертензії:

1. Артеріальна легенева гіпертензія; сюди відносять спадкову, ідіопатичну, асоційовану з лікарськими засобами та токсичними речовинами, пов'язану 3 хворобами сполучної тканини.

2. Легенева гіпертензія пов'язана з ураженням лівих відділів серця - порушення систолічної чи діастолічної функції Лш, набутий чи/або вроджений стеноз легеневих вен.

3. Лг унаслідок ураження легень та/або гіпоксемії - інтерстиційні хвороби легень, хронічні захворювання легень та інші.

4. Хронічна тромбоемболічна легенева гіпертензія.

5. Легенева гіпертензія нез'ясованої етіології чи багатьох причин - онкопроцеси, метаболічні захворювання, хронічна ниркова недостатність [27, 30].

Хронічна тромбоемболічна легенева гіпертензія, спричинена тривалою закупоркою головної легеневої артерії тромбом [8]. У 20 \% пацієнтів із цієї групи підтвердили наявність АФА, разом з тим, коли у пацієнтів інших груп АФА були у дуже малій кількості, або взагалі відсутні. У позитивних АФА хворих із хронічною тромбоемболічною легеневою гіпертензією АФС вважається діагностованим за наявності клінічних і лабораторних підтверджень цього $[1,3]$.

АФА впливають на реологічні властивості крові та погіршують мікроциркуляцію внутрішніх органів та гемодинаміку загалом, зумовлюють активацію оксидативних процесів і збільшують гіпоксію тканин [17].

У більшості пацієнтів спостерігається швидка втомлюваність при фрізичному навантаженні та прогресуюча задишка. В тяжчих випадках відмічається запаморочення, дискомфорт за грудниною та епізоди короткотривалої втрати свідомості. Це все $€$ наслідком зменшеного серцевого викиду через правошлуночкову недостатність [30].

Запорукою успішного прогнозу при лГ є її рання діагностика. Рання верифрікація дає змогу вчасно призначити терапію та спрогнозувати і запобігти наслідкам. Золотим стандартом діагностики легеневої гіпертензії є вимірювання тиску в легеневій артерії завдяки її катетеризації [28, 29]. Далі проводять гострий вазореактивний тест із вазодилататором (нітроген оксид, простациклін чи аденозин внутрішньовенно).

Перфрузійна сцинтиграфрія легень є більш чутлива, ніж ангіограсрія легень. Основне дослідження у 
діагностиці тромбоемболічної легеневої гіпертензії є візуалізація сегментарних та більших дефективних ділянок перфузії [26, 31].

ЕхоКГ важливо для постановки діагнозу та причин його виникнення. Можна побачити зміни при ЛГ - збільшення розмірів ПШ та розширення стовбура ЛА, в тяжчій стадії також збільшення порожнини і правого передсердя та деформація й зменшення лівого шлуночка та лівого передсердя доплерівське сканування виконується для дослідження тиску в ЛА та аналізу регургітаційних потоків правої частини серця [24, 26].

Рентгенографрія ОГК: збільшення правого шлуночка і правого передсердя, розширення легеневого стовбура і відгалужень правої легеневої артерії. Ознаки застою в малому колі кровобігу при лівошлуночковій недостатності, що призводить до лГ $[24,26,30]$.

ЕКГ може бути нормальним на ранніх термінах ЛГ, далі правограма P pulmonale, ознаки гіпертроорії та перевантаження ПШ і блокада правої ніжки пучка Гіса [27].

Дослідження легень: спірометрія - ознаки рестрикції чи обструкції на фроні ураження легень чи бронхів, які призвели до ЛГ; часто може бути в нормі. Плетизмографрія та дифузійна здатність легень виконується для підтвердження інтерстиціальних легеневих хвороб [31].

Лабораторні аналізи не мають специфрічних змін [24, 26, 27, 29, 30].

Хоча показник розвитку катастрофрічної фрорми серед пацієнтів з АФС $€$ невеликою, проте смертність при ній досить висока $[1,5]$. КАФС характеризується множинним тромбозом дрібних кровоносних судин, циркулюючими АФА та поліорганним інфрарктом, який щодня втягує більше органів. Головним легеневим ускладненням при КАФС є гострий респіраторний дистрес-синдром (ГРДС) [1, 8, 10].

Ушкодження альвеолярної структури та порушення мікроциркуляції призводить до інтерстиціального та внутрішньоальвеолярного затоплення рідиною, багатою на білки, так званої ексудативної фрази [31]. У цій фразі активуються резидентні альвеолярні макрофраги, що вивільняють сильні прозапальні медіатори та хемокіни, які сприяють накопиченню нейтросрілів та моноцитів. Останні вивільняють токсичні медіатори, які підвищують проникність судинної стінки для плазми та еритроцитів із подальшим розвитком легеневого набряку і ателектазу [32]. Через альвеолярну гіповентиляцію порушується рівновага між дифузією вуглекислого газу та кисню $[31,32]$.

Згідно з класифікацією, гострий респіраторний дистрес-синдром має 3 стадії: I - гостре ушкодження легень (зворотня), II - прогресуюча легенева недостатність, III - наслідки [31].

ГРДС, Берлінські критерії, JАМА 2012:
1. Гострий початок - менше 1 тижня від клінічної маніфестації чи поява нових симптомів дихальних розладів та їх прогресування.

2. Походження набряку - дихальна недостатність не зовсім $€$ наслідком серцевої недостатності чи надлишку рідини. Додатково потрібно ЕхоКГ для виключення гідростатичної причини набряку, без інших фракторів ризику.

3. Ступінь порушення оксигенації (потрібні дані пацієнта про рівень газів артеріальної крові):

- Легкий ГРДС $\mathrm{PaO}_{2} / \mathrm{FiO}^{2} 200<\mathrm{x} \leq 300$ з PЕЕР або СРАР $\geq 5 \mathrm{CM} \mathrm{H}_{2} \mathrm{O}$;

- Помірний ГРДС $\mathrm{PaO}_{2} / \mathrm{FiO}_{2} 100<\mathrm{x} \leq 200$ з РЕЕР $\geq 5 \mathrm{cM} \mathrm{H}_{2} \mathrm{O}$; $\mathrm{H}_{2} \mathrm{O}$.

- Тяжкий ГРДС $\mathrm{PaO}_{2} / \mathrm{FiO}_{2} \mathrm{x} \leq 100$ з PЕЕР $\geq 5$ cм

Якщо висота над рівнем моря перевищує 1000 м, то поправочний коефіцієнт необхідно обчисляти наступним чином: $\mathrm{PaO}_{2} / \mathrm{FiO}_{2}$ х барометричний тиск / 760 мм рт. ст.

4. Двобічні інфільтрати, що не повністю можна пояснити випотом, ателектазом легень чи вузликами на рентгенограмі/КТ органів грудної клітки [33, 34].

Етіологія ГРДС у хворих 3 АФС не $є$ до кінця з'ясованою. АФА також були знайдені у набряковій рідині, тобто це підтверджує гіпотезу, що АФА можуть сприяти розвитку гострого респіраторного дистрес-синдрому у пацієнтів 3 АФС [1, 3].

Дифузна альвеолярна кровотеча розвивається як наслідок ураження дрібних легеневих судин, що призводить до скупчення крові в альвеолах. Це, у свою чергу, порушує газообмін у легенях [35].

Такий стан зумовлений травмою чи запаленням артеріол, венул чи альвеолярної прегородки. Кровохаркання є найпоширенішим проявом, хоча у 33\% випадків він відсутній навіть за умов сильної кровотечі [1]. Цей прояв характерний для пацієнтів, у яких спочатку з'являється кашель, лихоманка, задишка та плевральний біль. Точна частота виникнення ДАК у пацієнтів з антифосороліпідним синдромом залишається невизначена [10]. $€$ припущення, що це може бути первинним проявом АФС. Легеневий капілярит є однією з трьох різних гістопатологічних картин при дифузній альвеолярній кровотечі й виникає в АФА позитивних хворих $[1,28]$.

Ідіопатичний фріброзуючий альвеоліт - особлива фрорма хронічної прогресуючої фріброзуючої інтерстиціальної пневмонії нез'ясованого генезу, яка зазвичай виникає у людей старшого віку. Уражає лише легені й гістологічно чи рентгенологічно пов'язана 3 картиною звичайної інтерстиціальної пневмонії [36].

Початок хвороби латентний, задишка та сухий кашель наростають упродовж тривалого часу (місяці). Можлива втрата маси та загальна слабість, поверхневе і пришвидшене дихання, крепітація у нижній частині легень $[12,37]$. У пізній стадії розвивається легеневе серце, фрормується симптом 
«барабанних паличок». Хвороба носить хронічно прогресуючий перебіг із нечастими загостреннями. Загострення проявляються задишкою чи її посиленням упродовж місяця з наявністю нової легеневої дисемінації, що втягує альвеоли (білатеральні зміни за типом матового скла та/чи ущільнення легеневої паренхіми [37].

У деякій літературі згадується про так званий післяпологовий синдром, що має клінічну картину легеневих проявів АФС [37]. В одній із них описуються прояви плевриту, задишки, лихоманки. При рентгенологічному дослідженні були виявлені дифрузні інфрільтрати та плевральний випіт [36]. У іншій описано клінічний випадок жінки після пологів, у якої виникли порушення серцевої провідності, легеневі прояви, лихоманка та ниркова недостатність після тяжкої преклампсії. Ці випадки схожі до проявів катастрофрічного АФС із поліорганною недостатністю і більше жодних згадок про нових пацієнтів не було $[1,12]$

Ще одне інорекційне захворювання, яке на даний час є надзвичайно актуальним для вивчення, $\epsilon$ SARS-CoV-2, при якому теж у багатьох хворих виявляють антифосфроліпідні антитіла. Їх утворення можливе двома шляхами, відомими на сьогодні це молекулярна імітація та утворення неоепітопів [18]. Вірус COVID-19 має 4 структурні протеїни: S-білок - «шип», M - мембранний, E - оболонковий, $\mathrm{N}$ - нуклеокапсид. Тримірний трансмембранний глікопротеїн S має дві субодиниці S1 та S2, які визначають варіабельність вірусу та тропізм господаря. S1 відповідає за приєднання вірусу до рецептора клітин господаря, а S2 сприяє злиттю вірусного капсиду з мембраною клітини [17]. Після приєднання до рецептора білок S розщеплюється протеазою, що призводить до ендоцитозу вірусної частинки. Саме за рахунок фуриноподібного роздвоєння білка S вірус відрізняється від SARS-CoV i, таким чином, має можливість повністю відділитись від вірусного капсиду [9, 17].

Ангіотензинперетворювальний фрермент 2 діє як вірусний рецептор на поверхнях кількох типів клітин легень та інших органів, зокрема на поверхні ендотелію і це допомагає вірусу зв'язуватись 3 клітинами-мішенями та проникати всередину них. Саме тому частими ускладненнями SARS-CoV2 $€$ тромбози, ДВЗ-синдром і системні васкуліти [18].

Було проведено ряд досліджень, в яких вивчали причини утворення антифосфоліпідних, вовчакових антитіл та анти- $\beta_{2}$-глікопротеїну-І у пацієнтів з COVID-19. Вони показали, що присутність цих антитіл у ковідних хворих не несе серйозного клінічного значення, тому що такі тести можуть бути хибнопозитивними на фроні ситемного запалення чи тимчасовими у цих хворих $[17,18]$.

Докази того, чи можуть АФА-позитивні пацієнти 3 COVID-19 мати вищий ризик тромботичних ускладень, $€$ неоднозначними. В деяких статтях $€$ підтвердження, що присутність АФА в інорікованих хворих жодним чином не впливає на збільшеня тромбозу, з іншого боку, навпаки, у когорти пацієнтів із COVID-19 результати тестів свідчать про значне підвищення тромбоутворення [18].

\section{ВИСНОВКИ}

Антифросфоліпідний синдром був відкритий досить недавно, тому етіологія, патогенез і шляхи його активації вивчені недостатньо. У даній статті ми звернули увагу та розкрили можливі варіанти його впливу на дихальну систему. Хвороби органів дихання займають провідне місце серед захворювань працездатного населення. Сукупність одночасно кількох легеневих патологій часто призводить до тяжкого перебігу та летальних наслідків. Неоднозначність досліджень на тему антифосфоліпідного синдрому вимагає більш точного вивчення. Тому на даний час, в умовах світової пандемії дослідження бронхолегеневої системи під впливом різних фракторів, таких, як віруси, бактерії, автоімунні системні захворювання, екологія та ятрогенія тощо, $є$ надзвичайно актуальними. Впровадження результатів дослідження в різні сфери медицини і науки внесе значний вклад у розвиток нових методів лікування і подальше ведення хворих.

\section{СПИСОК ЛІТЕРАТУРИ}

1. Antiphospholipid syndrome and the lungs / S. Yılmaz, Z. Yılmaz // European Medical Journal. - 2017. - Vol. 2 (1). - P. 76-82.

2. Антифроссроліпідний синдром: сучасний погляд на добре відому проблему / Ю.О.Дубоссарська // Медичні аспекти здоров'я жінки. - 2018. - № 1 (114). - С. 27-29

3. Продукция активных фрорм кислорода и развитие апоптоза в лейкоцитах крови при экспериментальном антифоссролипидном синдроме / О. 3. Яремчук, Е. А. Посохова, П. Г. Лихацкий [и др.] // Georgian Medical News. - 2020. - № 2(299). - P. 120-125.

4. Antiphospholipid syndrome / M. Petri // HHS Public
Access Author manuscript. - 2020. - Vol. 225. - P. 70-81. DOI: 10.1016/j.trsl.2020.04.006.

5. Показники прооксидантно-антиоксидантної системи печінки при експериментальному антифосфоліпідному синдромі та застосуванні L-аргініну / O. 3. Яремчук, [та ін.] // Медична та клінічна хімія. - 2017. - № 3. C. 63-70.

6. Васильев Д. В. Антифоссролипидный синдром: клиника и генетика тромботических проявлений / Д. В. Васильев, Л. В. Чернобай, О. В. Васильева // Український журнал медицини, біології та спорту. - 2017. № 2 (4). - C. 161-167.
$4(10), 2021$ 
7. Pulmonary hypertension associated with antiphospholipid antibody: Call for a screening tool? / R. Parthvi, R. Sikachi, A. Agrawal [et al.] // Intractable Rare Dis Res. - 2017. - Vol. 6 (3). - P. 163-171.

8. Lung disease in antiphospholipid syndrome / G. Maioli, G. Calabrese, F. Capsoni [et al.] // Semin. Respir. Crit. Care Med. - 2019. - Vol. 40 (2). - P. 278-294.

9. Anti-phospholipid syndrome and COVID-19 thrombosis: connecting the dots / M. L. T. Bryce Tan, R. Cherian, B. Chandra // Rheumatology Advances in Practice. - 2021. - P. 1-14.

10. Антифроссроліпідний синдром під маскою легеневої патології: клінічні спостереження пульмонолога / О.К.Яковенко, С. Л. Гріфрф, Т. Л. Яковенко // Конфреренція «Захворювання дихальних шляхів». Клінічна імунологія. Алергологія. Інфектологія. - 2019. - № 7 (120). - С. 14-23.

11. In vivo role of neutrophil extracellular traps in antiphospholipid antibody-mediated venous thrombosis / H. Meng, S. Yalavarthi, Y. Kanthi [et al.] // Arthritis Rheumatol. - 2017. - Vol. 69. - P. 655-667. DOI: 10.1002/art.39938.

12. The $\mathrm{H} 1$ haplotype of the endothelial protein $\mathrm{C}$ receptor protects against arterial thrombosis in patients with antiphospholipid syndrome / M. A. Plasin-Rodriguez, I. Rodriguez-Pinto, P. Patricio [et al.] // Thromb. Res. - 2018. - Vol. 169. - P. 128-134. DOI: 10.1016/j. thromres.2018.07.006.

13. Cellular and molecular mechanisms of antiphospholipid syndrome / M. Radic, D. Pattanaik // Frontiers in Immunology. - 2018. - Vol. 9. Article 969.

14. New biomarkers for atherothrombosis in antiphospholipid syndrome: Genomics and epigenetics approaches / Ch. Lopez-Pedrera, N. Barbarroja, A. Ma Patiño-Trives [et al.] // Front. Immunol. - 2019. Vol. 10. DOI: 10.3389/fimmu.2019.00764.

15. New insight into antiphospholipid syndrome: antibodies to $\beta_{2}$ glycoprotein I-domain 5 fail to induce thrombi in rats / P. Durigutto, C. Grossi, M. O. Borghi [et al.] // Haematologica. - 2019. - Vol. 104 (4). - P. 819-826.

16. Антисросфоліпідний синдром (АФС, синдром X'юза) / https://empendium.com/ua/chapter/B27.II.16.4 // Published 2018.

17. Antiphospholipid antibodies in patients with COVID-19: a relevant observation? / K. M. J. Devreese, E. A. Linskens, D. Benoit, H. Peperstraete // J. Thromb. Haemost. - 2020. - DOI: 10.1111/jth.14994.

18. COVID-19, antiphospholipid antibodies, and catastrophic antiphospholipid syndrome: A possible association? / G. El Hasbani, A. T. Taher, A. Jawad, I. Uthman // Clinical Medicine Insights: Arthritis and Musculoskeletal Disorders. - 2020. - Vol. 13. - P. 1-8.

19. Свінціцький А. С. Тромбоемболія легеневої артерії (ТЕЛА) / А. С. Свінціцький, П. Гаєвські // Внутрішні хвороби. - 2018/19. https://empendium.com/ua/chapter/ B27.II.2.33.2

20. Венозна тромбоемболія: тягар хвороби та її ризики / Підготовлено за матеріалами виступу Ajay Kakkar на пленарній сесії «VTE Safety Zone», жовтень 2018 р., Дубай (ОАЕ) // Український медичний часопис. - 2019. № 3 (131), T. 1.

21. Тромбоемболія легеневої артерії / Настанова 3 кардіології (за ред. В. М. Коваленка, 2009). https:// compendium.com.ua/uk/clinical-guidelines-uk/cardiologyuk/section-10-uk/tromboemboliya-legenevoyi-arteriyi/
22. Тромбоемболія легеневої артерії: етіологія, патогенез, діагностика. Лікування та профрілактика / Ю. С. Хмельницька - 2018. https://www.webcardio.org/Forums/ Thread. aspx ?thread $=83 \&$ mid $=34$ \&pageid $=5 \& \mid t e m I D=7$.

23. Pulmonary Embolism (PE) / D. R. Ouellette, A. Harrington // https://emedicine.medscape.com/ article/300901-overview. - 2020.

24. Pulmonary embolism (Blood Clot in Lung): Symptoms and More / Medically reviewed by Raj Dasgupta, MD - Written by Brian Krans // https://www.healthline.com/ health/pulmonary-embolus. - 2021.

25. Imaging of acute pulmonary embolism: an update / A. J. E. Moore, J. Wachsmann, M. R. Chamarthy [et al.] // Cardiovasc. Diagn. Ther. - 2018. - Vol. 8 (3). - P. 225-243.

26. Легенева гіпертензія, асоційована із системними захворюваннями сполучної тканини: сучасні підходи до ранньої діагностики / І. Ю. Головач, Є. Д. Єгудіна // Практикуючий лікар. - 2019. - Т. 8, № 1. - С. 10-19.

27. Легенева гіпертензія (ЛГ) / https://empendium. com/ua/chapter/B27.II.2.21. - 2018.

28. Проценко Г. О. Легенева гіпертензія у хворих на системну склеродермію / Г.О. Проценко, Ю. М. Сіренко // Український ревматологічний журнал. - 2016. - № 4 (66). - С. 75-78.

29. Pulmonary hypertension due to left heart disease / J.-L. Vachiéry, R. J. Tedford, S. Rosenkranz [et al.] // Eur. Respir. J. - 2019. - Vol. 53 (1). - P. 180-189. DOI: 10.1183/13993003.01897-2018.

30. Haemodynamic definitions and updated clinical classification of pulmonary hypertension / G. Simonneau, D. Montani, D. S. Celermajer [et al.] // Eur. Respir. J. - 2019. - Vol. 53 (1). - P. 180-1913. DOI: 10.1183/13993003.019132018

31. Гострий респіраторний дистрес синдром / В. І. Денесюк, О. В. Денесюк ; за ред. В. М. Коваленка // Внутрішня медицина. - 2019. Джерело: https:// compendium.com.ua/uk/tutorials-uk/vnutrishnyameditsina/3-rozdil-zakhvoriuvannia-orhaniv-dykhannia/3-9gostrij-respiratornij-distres-sindrom/

32. Thompson B. T. Acute respiratory distress syndrome / B. T. Thompson, R. C. Chambers, K. D. Liu // The New England Journal of Medicine. - 2017. - Vol. 377 (6). P. 562-572.

33. Тренінг з надання екстреної допомоги при важкій гострій респіраторній вірусній інфекції (ГРВІ) / Клінічні синдроми // Центр громадського здоров'я МО3, 2019.

34. Acute respiratory distress syndrome / M. Confalonieri, F. Salton, F. Fabiano // Eur. Respir. Rev. 2017. - Vol. 26. - P. 116-160. DOI: 10.1183/16000617.01162016.

35. Stoots S. A. Clinical insights into diffuse alveolar hemorrhage in antiphospholipid syndrome / S. A. Stoots, L. Lief, D. Erkan // Curr. Rheumatol. Rep. - 2019. - Vol. 21 (10). - P. 56. DOI: 10.1007/s11926-019-0852-7

36. Современные представления об идиопатическом фриброзирующем альвеолите / Л. А. Ковалевская, Т. Н. Горбенко, Р. А. Жураковский [та ін.] // Актуальные проблемы транспортной медицины. - 2017. - № 4 (50). - C. 81-88.

37. Ідіопатичний легеневий фріброз (ідіопатичний фріброзуючий альвеоліт, ІЛФ) / Внутрішні хвороби. -2018/19. https://empendium.com/ua/chapter/B27.II.3.12.1.1. 


\section{REFERENCES}

1. Yılmaz S, Yılmaz Z. Antiphospholipid syndrome and the lungs. European Medical Journal. 2017;2(1): 76-82.

2. Dubossarska Yu. O. [Antiphospholipid syndrome: a modern look at a well-known problem]. Medychni aspekty zdorovia zhinky. 2018;1(114): 27-9. Ukrainian.

3. Yaremchuk OZ, Posokhova EA, Lykhatskyy $\mathrm{PH}$, Letnyak NYa, Kulytskaya MY, Kuzmak IP et al. [Production of reactive oxygen species and the development of apoptosis in blood leukocytes in experimental antiphospholipid syndrome]. Georgian Medical News. - 2020;2(299): 120-5. Ukrainian.

4. Petri M. Antiphospholipid Syndrome. HHS Public Access Author manuscript. 2020;225: 70-81. DOI:10.1016/j. trsl.2020.04.006.

5. Yaremchuk OZ, Posokhova KA, Bryk AR, Kulits'ka MI, Kuzmak IP, Mekhno NYa. [Indicators of the prooxidant-antioxidant system of the liver in experimental antiphospholipid syndrome and the use of L-arginine]. Medychna ta klinichna khimiia. 2017;3: 63-70. Ukrainian.

6. Vasilyev DV, Chernobay LV, Vasilyeva OV. [Antiphospholipid syndrome: clinical picture and genetics of thrombotic manifestations]. Ukrainskyi zhurnal medytsyny, biolohiyi ta sportu. 2017;2(4): 161-7. Ukrainian.

7. Parthvi R, Sikachi R, Agrawal A, Adial A, Vulisha A, Khanijo S. Pulmonary hypertension associated with antiphospholipid antibody: Call for a screening tool? Intractable Rare Dis Res. 2017;6(3): 163-71.

8. Maioli G, Calabrese G, Capsoni F, Gerosa M, Luigi Meroni P, Chighizola B. Lung disease in antiphospholipid syndrome. Semin Respir Crit Care Med. 2019;40(2): 27894.

9. Bryce Tan MLT, Cherian R, Chandra B. Antiphospholipid syndrome and COVID-19 thrombosis: connecting the dots. Rheumatology Advances in Practice. 2021; 1-14.

10. Yakovenko OK, Hriff SL, Yakovenko TL. [Antiphospholipid syndrome under the mask of pulmonary pathology: clinical observations of a pulmonologist]. Konferentsiia «Zakhvoryuvannia dykhalnykh shliakhiv». Klinichna imunolohiia. Alerholohiia. Infektolohiia. 2019;7(120): 14-23. Ukrainian.

11. Meng H, Yalavarthi S, Kanthi Y, Mazza LF, Elfline MA, Luke CE, et al. In vivo role of neutrophil extracellular traps in antiphospholipid antibody-mediated venous thrombosis. Arthritis Rheumatol. 2017;69: 655-67. DOI: 10.1002/ art.39938

12. Plasin-Rodriguez MA, Rodriguez-Pinto I, Patricio P, Monteagudo J, Cervera R, Reverter JC, et al. The $\mathrm{H} 1$ haplotype of the endothelial protein $C$ receptor protects against arterial thrombosis in patients with antiphospholipid syndrome. Thromb Res. 2018;169: 128-34. DOI: 10.1016/j. thromres.2018.07.006

13. Radic M, Pattanaik D. Cellular and molecular mechanisms of anti-phospholipid syndrome. Frontiers in Immunology. 2018;9. Article 969.

14. Lopez-Pedrera Ch, Barbarroja N, Patiño-Trives $\mathrm{AM}^{\mathrm{a}}$, Collantes E, Aguirre $\mathrm{M}^{\mathrm{a}} \mathrm{A}$, Perez-Sanchez C. New biomarkers for atherothrombosis in antiphospholipid syndrome: Genomics and epigenetics approaches. Front Immunol. 2019; 10. Available from: https://doi.org/10.3389/ fimmu.2019.00764

15. Durigutto P, Grossi C, Borghi MO, Macor P, Pregnolato
F, Raschi E et al. New insight into antiphospholipid syndrome: antibodies to $\beta 2$ glycoprotein I-domain 5 fail to induce thrombi in rats. Haematologica. 2019;104(4): 81926.

16. Antiphospholipid syndrome (APS, Hughes syndrome). [Electronic resource]. Available from: https:// empendium.com/ua/chapter/B27.II.16.4 // Published 2018. Ukrainian.

17. Devreese KM.J, Linskens EA, Benoit D, Peperstraete $\mathrm{H}$. Antiphospholipid antibodies in patients with COVID-19: a relevant observation. J Thromb Haemost. 2020. DOI: 10.1111/jth.14994.

18. Hasbani GEI, Taher AT, Jawad A, Uthman I. COVID-19, Antiphospholipid antibodies, and catastrophic antiphospholipid syndrome: A possible association? Clinical Medicine Insights: Arthritis and Musculoskeletal Disorders. 2020;13: 1-8.

19. Svintsitskyy AS, Hayevski P. [Pulmonary embolism]. Vnutrishni khvoroby. 2018;19. Available from: https:// empendium.com/ua/chapter/B27.II.2.33.2. Ukrainian.

20. [Venous thromboembolism: the burden of the disease and its risks]. Ukr med chasop. 2019;3(131). Ukrainian.

21. Kovalenko VM Ed. Pulmonary artery thromboembolism. Guidelines for cardiology. Available from: https://compendium.com.ua/uk/clinical-guidelines-uk/ cardiology-uk/section-10-uk/tromboemboliya-legenevoyiarteriyi/ Ukrainian.

22. Khmelnytska YuS. [Pulmonary artery thromboembolism: etiology, pathogenesis, diagnosis]. 2018. Available from: https://www.webcardio.org/Forums/ Thread. asp $x$ ?thread=83\& $\mathrm{mid}=34$ \&pageid $=5 \& \mathrm{ItemID}=7$. Ukrainian.

23. Ouellette DR, Harrington A. Pulmonary Embolism. 2020; Available from: https://emedicine.medscape.com/ article/300901-overview.

24. Medically reviewed by Raj Dasgupta, MD - Written by Brian Krans. Pulmonary Embolism (Blood Clot in Lung): Symptoms and More. 2021. Available from: https://www. healthline.com/health/pulmonary-embolus.

25. Moore AJE, Wachsmann J, Chamarthy MR, Panjikaran L, Tanabe L, Rajiah P.. Imaging of acute pulmonary embolism: an update. Cardiovasc Diagn Ther. 2018;8(3): 225-43.

26. Holovach IYu, Yehudina YeD. [Pulmonary hypertension associated with systemic connective tissue diseases: modern approaches to early diagnosis]. Praktykuiuchyi likar. 2019;8(1): 10-19. Ukrainian.

27. [Pulmonary hypertension (LH)]. 2018. Available from: https://empendium.com/ua/chapter/B27.II.2.21 Ukrainian.

28. Protsenko HO, Sirenko YUM. [Pulmonary hypertension in patients with systemic scleroderma]. Ukrayinskyi revmatolohichnyi zhurnal. 2016;4(66): 75-8. Ukrainian.

29. Vachiéry JL, Tedford RJ, Rosenkranz S, Palazzini M, Lang I, Guazzi M, et al. Pulmonary hypertension due to left heart disease. Eur Respir J. 2019;53(1): 180-9. doi: 10.1183/13993003.01897-2018.

30. Simonneau G, Montani D, Celermajer DS, Denton CP, Gatzoulis MA, Krowka M, at all. Haemodynamic definitions and updated clinical classification of pulmonary hypertension. Eur Respir J. 2019;53(1): 180-191. DOI: 10.1183/13993003.01913-2018 
31. Denesyuk VI, Denesyuk OV, Kovalenko VM Ed. [Acute respiratory distress syndrome]. Vnutrishnia medytsyna. 2019. Available from: https://compendium. com.ua/uk/tutorials-uk/vnutrishnya-meditsina/3rozdil-zakhvoriuvannia-orhaniv-dykhannia/3-9-gostrijrespiratornij-distres-sindrom/ Ukrainian.

32. Thompson BT, Chambers RC, Liu KD. Acute respiratory distress syndrome. The New England Journal of Medicine. 2017;377(6): 562-72.

33. Training in emergency care for severe acute respiratory viral infection (SARS). Clinical syndromes; Public Health Center of the Ministry of Health; 2019.

34. Confalonieri M, Salton F, Fabiano F. Acute respiratory distress syndrome. Eur Respir Rev. 2017;26: 160-16.
Available from: https://d+oi.org/10.1183/16000617.01162016.

35. Stoots SA, Lief L, Erkan D. Clinical insights into diffuse alveolar hemorrhage in antiphospholipid syndrome. Curr Rheumatol Rep. 2019;21(10): 56. DOI: 10.1007/ s11926-019-0852-7

36. Kovalevskaya LA, Horbenko TN, Zhurakovskyy RA, Shkolyarenko AP, Malynovskaya EN, Bohachyk ES. [Modern representations of idiopathic fibrosing alveolitis]. Aktualnye problemy transportnoy medytsyny. 2017;4(50): 81-8. Ukrainian.

37. [Idiopathic pulmonary fibrosis (idiopathic fibrosing alveolitis, ILF)]. Vnutrishni khvoroby. 2018;19. Available from: https://empendium.com/ua/chapter/B27.II.3.12.1.1. Ukrainian. 